\title{
Effect of Super-optimal Dose of NPK Fertilizers on Nutrient Harvest Index, Uptake and Soil Fertility Levels in Wheat Crop under a Maize (Zea mays L.)-Wheat (Triticum aestivum L. Cropping System)
}

\author{
Rajiv Rakshit ${ }^{1}$, A. K. Patra ${ }^{1}$, T. J. Purakayastha ${ }^{1}$, R. D. Singh ${ }^{1}$, H. Pathak ${ }^{2}$ and Shiva Dhar ${ }^{3}$ \\ ${ }^{1}$ Division of Soil Science and Agricultural Chemistry, IARI, New Delhi (110 012), India \\ ${ }^{2}$ CESCRA, NRL, IARI, New Delhi (110 012), India \\ ${ }^{3}$ Division of Agronomy, IARI, New Delhi (110 012), India
}

\section{Article History}

Manuscript No. AR736

Received in $27^{\text {th }}$ April, 2014

Received in revised form $11^{\text {th }}$ December, 2014

Accepted in final form $2^{\text {nd }}$ February, 2015

\section{Correspondence to}

${ }^{*} E$-mail: rajiv.ssaciari@gmail.com

\section{Keywords}

Super-optimal fertilizers, wheat, soil

fertility, nutrient uptake, NHI

\begin{abstract}
A field experiment was conducted in an Inceptisol (IARI, New Delhi, India) during 2010-2011 and 2011-2012 to investigate the effect of optimal (100\% NPK) to superoptimal doses $(200 \%$ NPK) of mineral fertilizer on yield attributes, nutrient harvest index and their uptake pattern in wheat (Triticum aestivum) crop under a maize-wheat cropping systems. Ten levels of fertilizer N, P and K along with $3 \%$ foliar spray of iron were laid out in a randomized manner in three replications. Proportionate increase in fertilizer doses of NPK increases the wheat grain $(+5.4-5.6 \%)$ and straw yield $(+5.1-$ $6.1 \%$ ), but the rate of increase in yield declines as we move from lower to higher doses. The change or increased yield under treatments representing higher doses of NPK is attributed to the increase number of spikes (+4.7-56\%) and the weight of grains in each spike ( $+5-6 \%)$. Super-optimal dose of mineral fertilizers $(200 \%$ NPK) application increased the nutrient contents and uptake of nutrients in grain and straw of wheat. Fertility status of soil after the harvest of two cycles of maize-wheat crop increased with increased application of N, P and K. Nutrient harvest indices for various nutrients showed the effectiveness of mineral fertilizers and foliar iron application increased iron harvest index $+9-20 \%$.
\end{abstract}

\section{Introduction}

Recent research conducted across the many Asian countries (Pathak et al., 2003) has demonstrated limitations of the current approach of fixed-rate, fixed-time fertilizer recommendations being made for large areas. This is mainly because this approach does not take into account the existence of large variability in soil nutrient supply and crop response to nutrients (Timsina and Connor, 2001). At issue then is whether the existing yield gaps can be further exploited through improved nutrient and crop management, and site-specific strategies of nutrient management might be able to restore the productivity growth of wheat in the coming decades (Chuan et al., 2013). The process of balancing crop nutrients involves adjustment of fertilizer recommendations to a particular crop, soil, yield goal, fertilizer availability, or resource level of the farmer. Fertilization on a farmers scale is dominated by the continuous use of $\mathrm{N}$ alone or combined with sub-optimal rates of other nutrients which have been the utmost reason for non sustainable yields in major crops (Chesti et al., 2013). In addition, the widespread use of macroelement fertilizers to raise crop yields makes them a convenient vehicle to supply crops with micronutrients as well. Most specifically, iron deficiency can limit crop yield, especially on high $\mathrm{pH}$ soils. If iron deficient areas within fields can be predicted accurately, site-specific use of iron fertilizers might be more profitable than uniform management. Based on soil properties, it has been found that microelements foliar application is more influential compared to soil application (Arif et al., 2006). Since in field situation, soil features and environmental factors which affect nutrients absorption are extremely changeable, foliar application could be an advantage for crop growth (Seifi Nadergholi et al., 2011). Our efforts were therefore, directed toward evaluating the application of optimal to super-optimal doses of NPK along with foliar spray of iron in wheat crops in terms of yield attributes, nutrient uptakes $(\mathrm{N}, \mathrm{P}$ and $\mathrm{K})$, nutrient harvest index as well as the available nutrients in soil. 


\section{Materials and Methods}

\subsection{Experimental condition and design}

The present study was undertaken at the experimental field of IARI, located at $28^{\circ} 37^{\prime}-28^{\circ} 39^{\prime} \mathrm{N}$ latitude and $77^{\circ} 9^{\prime}-77^{\circ} 11^{\prime}$ E longitude (about 250 masl), New Delhi, India. The soil was a fine loamy, slightly alkaline, moderately permeable, hyperthermic family of the Typic Haplustept (Table 1). Maize (variety HQPM-1) was sown in the $3^{\text {rd }}$ week of July in each cropping season (kharif 2010 and kharif 2011) in fixed plots and harvested on $3^{\text {rd }}$ week of October, 2010 and 2011 respectively. Wheat (variety HD-2687) was sown in the second week of November in each cropping season (rabi, 2010 and rabi, 2011) and harvested on $3^{\text {rd }}$ week of April, 2011 and 2012 respectively. Standard agronomic package of practices were followed for both the crops. In this study, a randomised block design was adopted in the experimental field and ten treatments with three replicates each were chosen as follows: 100\% NPK; $125 \%$ NPK; $150 \%$ NPK; $175 \%$ NPK; 200\% NPK; 100\% NPK+Fe; $125 \% \mathrm{NPK}+\mathrm{Fe} ; 150 \% \mathrm{NPK}+\mathrm{Fe} ; 175 \% \mathrm{NPK}+\mathrm{Fe} ; 200 \%$ $\mathrm{NPK}+\mathrm{Fe}$. The recommended dose of wheat is $120-25.8-33.2$ $\mathrm{kg} \mathrm{N}-\mathrm{P}-\mathrm{K} \mathrm{ha}^{-1}$ (100\% NPK). Urea, DAP and MOP was used as the source of $\mathrm{N}, \mathrm{P}$ and $\mathrm{K}$ respectively. As the available iron was found to be low under the experimental condition (Table 1), so it was essential to include the same in the applied treatments. Three foliar sprays of $3 \% \mathrm{FeSO}_{4} \cdot 7 \mathrm{H}_{2} \mathrm{O}$ each at the rate of 500 $\mathrm{L} \mathrm{ha}^{-1}$ were applied at 40, 60, and $75 \mathrm{DAS}$ of wheat. Thus, three foliar sprays required $45 \mathrm{~kg} \mathrm{FeSO}{ }_{4} .7 \mathrm{H}_{2} \mathrm{O} \mathrm{ha}{ }^{-1}$.

\subsection{Analysis of plant samples}

The plant samples were dried in oven at $65 \pm 1^{\circ} \mathrm{C}$ and ground thoroughly by a Wiley mill. A representative ground plant samples $(0.5 \mathrm{~g})$ was taken for digestion. For pre-digestion, samples were soaked overnight with $10 \mathrm{ml}$ of concentrated $\mathrm{HNO}_{3}$ and finally digested in a di-acid mixture $(8 \mathrm{ml})$ containing $\mathrm{HNO}_{3}$ and $\mathrm{HClO}_{4}$ acid (9:4) on an electric hot plate following the procedure described by Piper (1967). The digested material was cooled, diluted with distilled water and filtered through Whatman No. 1 filter paper. The volume was made upto 100 $\mathrm{ml}$ and stored in a polypropylene container $(125 \mathrm{ml})$ for further analysis. Total nitrogen in plant samples at maturity stage was estimated by Microkjeldahl method (Jackson, 1973). The total phosphorus content in the acid extract was determined after developing vanadomolybdo yellow colour complex in $\mathrm{HNO}_{3}$ medium (Jackson, 1973). Potassium concentrations in the digested plant extracts were determined by a flame photometer (Jackson, 1973).

\subsection{Analysis of soil samples (Available N, P and K)}

The alkaline potassium permanganate oxidized soil nitrogen was determined as per prescribed methodology of Subbiah and Asija, 1956. Phosphorus content in the extract was determined by ascorbic acid method (Watanabe and Olsen, 1965). The soil samples were extracted with $0.5 \mathrm{M} \mathrm{NaHCO}_{3}$; $\mathrm{pH}$ 8.5.
Available potassium was estimated flame photometrically in neutral normal ammonium acetate extract (Hanway and Heidel, 1952).

\subsection{Statistical analysis}

Data obtained from the field experiment was statistically analyzed following standard statistical methods (Gomez and Gomez, 1984). Analysis of variance pertaining to the different fertilizer treatments for comparison of means was performed using Microsoft Excel and MSTATC. Unless otherwise stated, the level of significance referred to in the results is $p<0.05$.

\section{Results and Discussion}

\subsection{Yield attributing characters}

Mean of 2 years data showed that the fertilizer treatments significantly increased the number of spikes $/ \mathrm{m}^{2}$ and grain weight/spike under $200 \%$ dose of fertilizers NPK in comparison to $100 \%$ NPK. Thus, the change or increased yield under treatments representing higher doses of NPK is attributed to the increase number of spikes and the weight of grains in each spike. Yield attributing characters like 1000 grain weight, grains per spike and harvest index were found to be at par over the various treatments (Table 2). These observations are in line with the work of Tripathi et al. (2013) who evaluated the different wheat varieties under various levels of nitrogen application and reported increase number of spikes $/ \mathrm{m}^{2}$ with application of higher dose of nitrogen (150\%).

\subsection{Grain and straw yield}

Application of $175 \%$ NPK dose brought a significant increase in the wheat grain yield as compared to $100 \%$ recommended dose of fertilizers. Over the two years, maximum increases in wheat grain yield were observed in $200 \%$ NPK or $200 \%$ $\mathrm{NPK}+\mathrm{Fe}$ treatments having $200 \%$ NPK dose followed by $175 \%$

Table 1: Physico-chemical properties of initial soil sample of experimental field

\begin{tabular}{|c|c|c|}
\hline $\begin{array}{l}\text { Sl. } \\
\text { No. }\end{array}$ & Soil Properties & Values \\
\hline 1. & $\mathrm{pH}(1: 2.5$ soil to water suspension ratio) & 8.39 \\
\hline 2. & $\mathrm{EC}\left(\mathrm{dS} \mathrm{m} \mathrm{m}^{-1}\right)$ & 0.33 \\
\hline 3. & Texture & Sandy loam \\
\hline 4. & Soil type & Typic haplustept \\
\hline 5. & Soil organic carbon $(\%)$ & 0.34 \\
\hline 6. & Alkaline $\mathrm{KMnO}_{4}-\mathrm{N}\left(\mathrm{kg} \mathrm{ha}^{-1}\right)$ & 223.31 \\
\hline 7. & Olsens'- $\mathrm{P}_{2} \mathrm{O}_{5}\left(\mathrm{~kg} \mathrm{ha}^{-1}\right)$ & 15.19 \\
\hline 8. & Ammonium acetate- $\mathrm{K}_{2} \mathrm{O}\left(\mathrm{kg} \mathrm{ha}^{-1}\right)$ & 209.07 \\
\hline 9. & DTPA extractable $\mathrm{Zn}\left(\mathrm{mg} \mathrm{kg}^{-1}\right)$ & 0.82 \\
\hline 10. & DTPA extractable Fe $\left(\mathrm{mg} \mathrm{kg}^{-1}\right)$ & 1.38 \\
\hline 11. & DTPA extractable $\mathrm{Mn}\left(\mathrm{mg} \mathrm{kg}^{-1}\right)$ & 3.61 \\
\hline 12. & DTPA extractable $\mathrm{Cu}\left(\mathrm{mg} \mathrm{kg}^{-1}\right)$ & 0.57 \\
\hline
\end{tabular}


NPK or $175 \% \mathrm{NPK}+\mathrm{Fe}$. The mean yield for the year 2010 2011 and 2011-2012 were observed to be 4.90 and $5.05 \mathrm{t} \mathrm{ha}^{-1}$ respectively (Table 3 ). Highest yield of $5.10 \mathrm{tha}^{-1}$ was obtained with the application of $200 \% \mathrm{NPK}+$ foliar $\mathrm{FeSO}_{4} \cdot 7 \mathrm{H}_{2} \mathrm{O} @ 3 \%$ $(200 \% \mathrm{NPK}+\mathrm{Fe})$. Bameri et al. (2012) also obtained their highest yield through $\mathrm{Fe}$ foliar application in combination with Mn fertiliser (@1.5\% Fe+Mn) followed by sole Fe application (a) $2.5 \% \mathrm{FeSO}_{4} .7 \mathrm{H}_{2} \mathrm{O}$. This result get hold because of iron is critical for chlorophyll formation and photosynthesis and is important in the enzyme systems and respiration of plants (Babaeian et al., 2011).

Straw yield followed the same trend as that of grain yield (Table
2). Application of $150 \%$ of recommended dose of NPK brought a significant increase in the straw yield. The mean straw yield for the year 2010-2011 and 2011-2012 were observed to be 7.82 and $7.94 \mathrm{t} \mathrm{ha}^{-1}$ respectively. Increase in fertilizer dose from 100 to $200 \%$ NPK caused an increase about $5-6 \%$ (over the two cropping seasons) in the straw yield. Fe foliar application did not show any significant result in increasing the straw yield. Similar results were obtained by Bameri et al. (2012). Liu et al. (2003) also revealed that the yield (grain+straw) increment was directly proportional to the rate of fertiliser application up to a certain fertiliser dose because the response of crops to fertilizer $\mathrm{N}$ mainly depends on soil $\mathrm{N}$ fertility, crop yield level and climatic conditions, so that the super optimal dose of $\mathrm{N}$

\begin{tabular}{|c|c|c|c|c|c|c|}
\hline Treatments & Plant height $(\mathrm{cm})$ & Spikes $\mathrm{m}^{2}$ & Grains spike $^{-1}$ & Grain weight spike $^{-1}(\mathrm{~g})$ & Test weight (g) & Harvest index $(\%)$ \\
\hline $100 \%$ NPK & 96.0 & 408 & 36.50 & 2.33 & 32.93 & 62.76 \\
\hline $125 \% \mathrm{NPK}$ & 97.0 & 419 & 36.40 & 2.39 & 32.77 & 62.95 \\
\hline $150 \% \mathrm{NPK}$ & 97.7 & 421 & 36.30 & 2.40 & 32.87 & 62.71 \\
\hline $175 \%$ NPK & 97.0 & 423 & 37.30 & 2.38 & 32.62 & 62.83 \\
\hline $200 \%$ NPK & 96.5 & 427 & 36.70 & 2.47 & 32.85 & 62.97 \\
\hline $100 \% \mathrm{NPK}+\mathrm{Fe}$ & 95.3 & 409 & 36.50 & 2.36 & 32.77 & 63.65 \\
\hline $125 \% \mathrm{NPK}+\mathrm{Fe}$ & 98.0 & 415 & 37.50 & 2.42 & 32.67 & 63.08 \\
\hline $150 \% \mathrm{NPK}+\mathrm{Fe}$ & 98.8 & 417 & 38.00 & 2.44 & 32.88 & 63.42 \\
\hline $175 \% \mathrm{NPK}+\mathrm{Fe}$ & 97.8 & 429 & 36.70 & 2.38 & 32.75 & 63.41 \\
\hline $200 \% \mathrm{NPK}+\mathrm{Fe}$ & 98.2 & 432 & 36.80 & 2.48 & 32.83 & 63.43 \\
\hline Mean & 97.23 & 420 & 36.87 & 2.41 & 32.80 & 63.12 \\
\hline $\operatorname{LSD}(p=0.05)$ & NS & 13 & NS & 0.11 & NS & NS \\
\hline
\end{tabular}

Table 3: Wheat grain and straw yield as influenced by different levels of fertilizer treatments

\begin{tabular}{lcccc}
\hline Treatment & \multicolumn{2}{c}{ Grain yield $\left(\mathrm{t} \mathrm{ha}^{-1}\right)$} & \multicolumn{2}{c}{ Straw yield $\left(\mathrm{t} \mathrm{ha}{ }^{-1}\right)$} \\
\cline { 2 - 6 } & $2010-$ & $2011-$ & $2010-$ & $2011-$ \\
& 2011 & 2012 & 2011 & 2012 \\
\hline $100 \% \mathrm{NPK}$ & 4.69 & 4.92 & 7.54 & 7.77 \\
$125 \% \mathrm{NPK}$ & 4.88 & 4.98 & 7.86 & 7.81 \\
$150 \% \mathrm{NPK}$ & 4.91 & 5.03 & 7.87 & 7.98 \\
$175 \% \mathrm{NPK}$ & 4.95 & 5.11 & 7.92 & 8.09 \\
$200 \% \mathrm{NPK}$ & 4.99 & 5.15 & 7.99 & 8.11 \\
$100 \% \mathrm{NPK}+\mathrm{Fe}$ & 4.77 & 4.88 & 7.47 & 7.69 \\
$125 \% \mathrm{NPK}+\mathrm{Fe}$ & 4.92 & 4.94 & 7.79 & 7.84 \\
$150 \% \mathrm{NPK}+\mathrm{Fe}$ & 4.94 & 5.08 & 7.81 & 7.99 \\
$175 \% \mathrm{NPK}+\mathrm{Fe}$ & 4.97 & 5.17 & 7.96 & 8.03 \\
$200 \% \mathrm{NPK}+\mathrm{Fe}$ & 5.01 & 5.19 & 8.01 & 8.07 \\
$\mathrm{LSD}(p=0.05)$ & \multicolumn{3}{c}{$\mathrm{T}-0.22$} & \multicolumn{2}{c}{$\mathrm{T}-0.39$} \\
& \multicolumn{3}{c}{$\mathrm{Y}-\mathrm{NS}$ - NS } \\
\hline \multicolumn{3}{c}{$\mathrm{T} \times \mathrm{Y}-\mathrm{NS}$} & \multicolumn{3}{c}{$\mathrm{Y}-\mathrm{NS}$} \\
\hline
\end{tabular}

may enhance crop yield.

\section{3. $N$ content and uptake in grain and straw}

Nitrogen concentration in grain of wheat as influenced by levels of different treatments and cropping seasons are shown in Table 4. At $200 \%$ NPK levels, it was found to be $1.94 \%$ which was statistically higher over the other treatments. Additional foliar application of iron sulphate did not affect the nitrogen content in grain. Fertilizer at recommended level of $100 \%$ NPK increased the nitrogen uptake from $86.84 \mathrm{~kg} \mathrm{ha}^{-1}$ to $98.79 \mathrm{~kg} \mathrm{ha}^{-1}$ at $200 \% \mathrm{NPK}+3 \% \mathrm{FeSO}_{4}$ spray. Considering all the treatments of the study, nitrogen uptake in grain was observed to be $89.76 \mathrm{~kg} \mathrm{ha}^{-1}$ in the first cropping season (20102011) and $94.46 \mathrm{~kg} \mathrm{ha}^{-1}$ in the second cycle (2011-2012) (Table 4). Lopez-Bellido and Lopez-Bellido (2001) also obtained the highest grain $\mathrm{N}$ uptake at higher rate of $\mathrm{N}$ application i.e. 150 $\mathrm{kg} \mathrm{N}$ ha ${ }^{-1}$ and $\mathrm{N}$ uptake increases with increased $\mathrm{N}$ application, but the grain $\mathrm{N}$ uptake did not varied significantly between the cropping seasons.

The data on the nitrogen content in straw in soil at maturity of wheat under varying levels of fertilizer-N application have 


\begin{tabular}{|c|c|c|c|c|c|c|c|c|}
\hline \multirow[t]{2}{*}{ Treatment } & \multicolumn{2}{|c|}{ Grain $\mathrm{N}$ content $(\%)$} & \multicolumn{2}{|c|}{ Grain N uptake } & \multicolumn{2}{|c|}{ Straw N content $(\%)$} & \multicolumn{2}{|c|}{ Straw N uptake } \\
\hline & $2010-2011$ & $2011-2012$ & $2010-2011$ & 2011-2012 & $2010-2011$ & $2011-2012$ & $2010-2011$ & $2011-2012$ \\
\hline $100 \% \mathrm{NPK}$ & 1.77 & 1.84 & 83.15 & 90.53 & 0.43 & 0.44 & 32.20 & 34.42 \\
\hline $125 \% \mathrm{NPK}$ & 1.79 & 1.84 & 87.21 & 91.48 & 0.45 & 0.46 & 35.13 & 35.69 \\
\hline $150 \%$ NPK & 1.82 & 1.84 & 89.51 & 92.70 & 0.46 & 0.47 & 35.97 & 37.75 \\
\hline $175 \%$ NPK & 1.84 & 1.87 & 90.93 & 95.56 & 0.47 & 0.48 & 37.46 & 39.07 \\
\hline $200 \%$ NPK & 1.93 & 1.96 & 96.31 & 100.79 & 0.50 & 0.50 & 39.71 & 40.79 \\
\hline $100 \% \mathrm{NPK}+\mathrm{Fe}$ & 1.79 & 1.83 & 85.38 & 89.45 & 0.41 & 0.45 & 30.85 & 34.37 \\
\hline $125 \% \mathrm{NPK}+\mathrm{Fe}$ & 1.79 & 1.84 & 87.92 & 90.9 & 0.42 & 0.47 & 32.95 & 36.85 \\
\hline $150 \% \mathrm{NPK}+\mathrm{Fe}$ & 1.83 & 1.86 & 90.55 & 94.64 & 0.45 & 0.48 & 35.38 & 38.11 \\
\hline $175 \% \mathrm{NPK}+\mathrm{Fe}$ & 1.84 & 1.86 & 91.45 & 96.16 & 0.47 & 0.50 & 37.41 & 39.91 \\
\hline $200 \% \mathrm{NPK}+\mathrm{Fe}$ & 1.90 & 1.97 & 95.19 & 102.4 & 0.50 & 0.50 & 39.81 & 40.59 \\
\hline \multirow[t]{3}{*}{$\operatorname{LSD}(p=0.05)$} & \multicolumn{2}{|c|}{ T- 0.04} & \multicolumn{2}{|c|}{ T- 5.65} & \multicolumn{2}{|c|}{ T- 0.023} & \multicolumn{2}{|c|}{ T- 3.92} \\
\hline & \multicolumn{2}{|c|}{ Y- 0.02} & \multicolumn{2}{|c|}{ Y- NS } & \multicolumn{2}{|c|}{ Y- NS } & \multicolumn{2}{|c|}{ Y- NS } \\
\hline & \multicolumn{2}{|c|}{$\mathrm{T} \times \mathrm{Y}-\mathrm{NS}$} & \multicolumn{2}{|c|}{$\mathrm{T} \times \mathrm{Y}-\mathrm{NS}$} & \multicolumn{2}{|c|}{$\mathrm{T} \times \mathrm{Y}-\mathrm{NS}$} & \multicolumn{2}{|c|}{$\mathrm{T} \times \mathrm{Y}-\mathrm{NS}$} \\
\hline
\end{tabular}

clearly shown the increasing nitrogen content with increasing levels of fertilization. Application of fertilizer dose at $100 \%$ NPK increased the nitrogen content in straw from $0.44 \%$ to $0.50 \%(200 \% \mathrm{NPK})$ levels. It is clearly evident from the results that $200 \%$ NPK levels manifested relatively higher nitrogen uptake in straw (Table 4). Nitrogen uptake in straw was highest in $200 \%$ NPK $\left(40.25 \mathrm{~kg} \mathrm{ha}^{-1}\right)$, followed by $200 \%$ $\mathrm{NPK}+3 \% \mathrm{FeSO}_{4}$ spray $\left(40.20 \mathrm{~kg} \mathrm{ha}^{-1}\right)$, while the lowest value was observed in the plot receiving $100 \%$ NPK $\left(33.31 \mathrm{~kg} \mathrm{ha}^{-1}\right)$. Specifically, the $175 \%$ NPK or $175 \%$ NPK + Fe treatments $(175 \%$ NPK) i.e. $75 \%$ increase in fertilization over the control $(100 \%)$ leads to a significant increase in the nitrogen uptake in straw, whereas straw nitrogen in $100 \%$ NPK, $125 \%$ NPK and $150 \%$ NPK treatments were statistically at par.

\subsection{P content and uptake in grain and straw}

Phosphorus content in grain increases with the increase in fertilization doses (Table 5). At 200\% NPK levels, it was found to be $0.418 \%$ which was statistically higher over the other treatments. Additional foliar application of iron sulphate did not affect the phosphorus content in grain. $75 \%$ increase in fertilization over the control $(100 \%)$ leads to a significant increase in the phosphorus content in grain, whereas grain phosphorus in $100 \%$ NPK, $125 \%$ NPK and $150 \%$ NPK treatments were statistically at par (Table 5). Fertilizer at recommended level of $100 \%$ NPK increased the grain phosphorus uptake from $18.26 \mathrm{~kg} \mathrm{ha}^{-1}$ to $21.35 \mathrm{~kg} \mathrm{ha}^{-1}$ at $200 \%$ $\mathrm{NPK}+3 \% \mathrm{FeSO}_{4}$ spray (Table 5). The $\mathrm{P}$ in the grain accounted for about $81 \%$ of $\mathrm{P}$ uptake in wheat (Tang et al., 2008). Vig

\begin{tabular}{|c|c|c|c|c|c|c|c|c|}
\hline \multirow[t]{2}{*}{ Treatment } & \multicolumn{2}{|c|}{ Grain P content $(\%)$} & \multicolumn{2}{|c|}{ Grain P uptake } & \multicolumn{2}{|c|}{ Straw P content $(\%)$} & \multicolumn{2}{|c|}{ Straw P uptake } \\
\hline & $2010-2011$ & 2011-2012 & $2010-2011$ & 2011-2012 & $2010-2011$ & $2011-2012$ & $2010-2011$ & $2011-2012$ \\
\hline $100 \%$ NPK & 0.379 & 0.381 & 17.78 & 18.75 & 0.04 & 0.042 & 3.02 & 3.26 \\
\hline $125 \% \mathrm{NPK}$ & 0.382 & 0.389 & 18.64 & 19.37 & 0.041 & 0.042 & 3.22 & 3.28 \\
\hline $150 \% \mathrm{NPK}$ & 0.389 & 0.392 & 19.1 & 19.72 & 0.046 & 0.047 & 3.62 & 3.75 \\
\hline $175 \% \mathrm{NPK}$ & 0.399 & 0.399 & 19.75 & 20.39 & 0.051 & 0.051 & 4.04 & 4.13 \\
\hline $200 \%$ NPK & 0.418 & 0.418 & 20.86 & 21.53 & 0.057 & 0.058 & 4.55 & 4.7 \\
\hline $100 \% \mathrm{NPK}+\mathrm{Fe}$ & 0.382 & 0.384 & 18.22 & 18.74 & 0.039 & 0.044 & 2.91 & 3.38 \\
\hline $125 \% \mathrm{NPK}+\mathrm{Fe}$ & 0.386 & 0.387 & 18.99 & 19.12 & 0.041 & 0.045 & 3.19 & 3.53 \\
\hline $150 \% \mathrm{NPK}+\mathrm{Fe}$ & 0.388 & 0.393 & 19.17 & 19.96 & 0.046 & 0.047 & 3.59 & 3.76 \\
\hline $175 \% \mathrm{NPK}+\mathrm{Fe}$ & 0.399 & 0.401 & 19.83 & 20.73 & 0.049 & 0.051 & 3.9 & 4.10 \\
\hline $200 \% \mathrm{NPK}+\mathrm{Fe}$ & 0.416 & 0.421 & 20.84 & 21.85 & 0.052 & 0.057 & 4.17 & 4.60 \\
\hline $\operatorname{LSD}(p=0.05)$ & $\begin{array}{l}\mathrm{T}- \\
\mathrm{Y}- \\
\mathrm{T} \times \mathrm{Y}\end{array}$ & $\begin{array}{l}.01 \\
\text { NS } \\
-\mathrm{NS}\end{array}$ & $\begin{array}{l}\mathrm{T}- \\
\mathrm{Y}- \\
\mathrm{T} \times \mathrm{Y}\end{array}$ & $\begin{array}{l}1.33 \\
\text { NS } \\
-\mathrm{NS}\end{array}$ & $\begin{array}{l}\mathrm{T}-0 \\
\mathrm{Y}-0 \\
\mathrm{~T} \times \mathrm{Y}\end{array}$ & $\begin{array}{l}.004 \\
.002 \\
-\mathrm{NS}\end{array}$ & $\begin{array}{l}\mathrm{T}- \\
\mathrm{Y} \\
\mathrm{T} \times\end{array}$ & $\begin{array}{l}.65 \\
\text { NS } \\
-\mathrm{NS}\end{array}$ \\
\hline
\end{tabular}


and Singh (1983) enumerated phosphorus application enhances wheat grain yield, consequently removal of phosphorous by wheat grains was significantly affected by the P level used irrespective of method of application. Total removal of $\mathrm{P}$ increased significantly with increase in P levels. Probably the greater availability of $\mathrm{P}$ to roots and lesser fraction of $\mathrm{P}$ absorbed by soil favoured greater P uptake (Costa et al., 2010). It was also found that $\mathrm{N}$ fertilisation plays a synergistic role for enhancing P uptake (Zhao, 2010) because nitrogen is also the key element in achieving consistently high yield in wheat so that the greater recovery of fertilizer $\mathrm{P}$ at higher level of fertilizer $\mathrm{N}$ was because of a greater uptake of $\mathrm{P}$ due to better crop growth (Singh et al., 2001).

Application of fertilizer dose at $100 \%$ NPK increased the phosphorus content in straw from $0.041 \%$ to $0.054 \%(200 \%$ NPK) levels. Phosphorus uptake in straw was highest in $200 \%$ NPK $\left(4.63 \mathrm{~kg} \mathrm{ha}^{-1}\right)$, followed by $200 \% \mathrm{NPK}+3 \% \mathrm{FeSO}_{4}$ spray $\left(4.38 \mathrm{~kg} \mathrm{ha}^{-1}\right)$, while the lowest value was observed in the control plot $\left(3.14 \mathrm{~kg} \mathrm{ha}^{-1}\right) .75 \%$ increase in fertilization over the control $(100 \%)$ leads to a significant increase in the phosphorus uptake in straw, whereas straw phosphorus in 100\% NPK, $125 \%$ NPK and $150 \%$ NPK treatments were statistically at par (Table 5).

\subsection{K content and uptake in grain and straw}

$50 \%$ increase in fertilization over $100 \%$ NPK causes a significant increase in the potassium content in grain, whereas grain potassium in $100 \%$ NPK and $125 \%$ NPK treatments were statistically at par (Table 6). Fertilizer at recommended level of $200 \%$ NPK along with $3 \% \mathrm{FeSO}_{4}$ spray increased the uptake of potassium by $48 \%$ as compared to $100 \%$ NPK. Cropping season and its interaction with the treatments did not produce any statistically significant results. Application of fertilizer dose at $100 \%$ NPK increased the potassium content in straw from $1.71 \%$ to $2.04 \%$ ( $200 \%$ NPK) levels. Potassium content in straw was observed to be $1.81 \%$ in the first cropping season (2010-2011) and $1.82 \%$ in the second cropping season (20112012). Hui-Min et al. (2011) found that grain K content was independent of level of $\mathrm{K}$ applied whereas $\mathrm{K}$ content in straw was significantly differ with the level of $\mathrm{K}$ applied in wheat under maize-wheat cropping system.

The effect of fertilizer treatments on potassium uptake in straw was significant $(p<0.05)$ but the effect of different cropping season was not significant (Table 6). Potassium uptake in straw was highest in the $200 \%$ NPK plots $\left(164.09 \mathrm{~kg} \mathrm{ha}^{-1}\right)$, followed by $200 \% \mathrm{NPK}+3 \% \mathrm{FeSO}_{4}$ spray $\left(163.08 \mathrm{~kg} \mathrm{ha}^{-1}\right)$, while the lowest value was observed in the $100 \%$ NPK plot $\left(130.52 \mathrm{~kg} \mathrm{ha}^{-1}\right)$.

\subsection{Available N, $P$ and $K$ in soils at various physiological} stages

The value of available nitrogen varies from $155.03-250.47 \mathrm{~kg}$ $\mathrm{ha}^{-1}$ in the year 2010-2011 and $168.75-260.33 \mathrm{~kg} \mathrm{ha}^{-1}$ in the cropping year 2011-2012. Data on available nitrogen over the various phenological stages reflects the prominence of $200 \%$ NPK or $200 \% \mathrm{NPK}+\mathrm{Fe}$ (Table 7); it is due to higher application of inorganic nitrogen in the form of urea. Available nitrogen is significantly higher in 200\% NPK (255.40 $\left.\mathrm{kg} \mathrm{ha}^{-1}\right)$ and 200\% $\mathrm{NPK}+\mathrm{Fe}\left(247.52 \mathrm{~kg} \mathrm{ha}^{-1}\right)$. For available nitrogen, the treatment effect can be arranged in the following order (based on statistical significance): $100 \%$ NPK or $100 \% \mathrm{NPK}+\mathrm{Fe}>125 \%$ $\mathrm{NPK}$ or $125 \% \mathrm{NPK}+\mathrm{Fe}>150 \% \mathrm{NPK}$ or $150 \% \mathrm{NPK}+\mathrm{Fe}>175 \%$ NPK or $175 \%$ NPK $+\mathrm{Fe}>200 \%$ NPK or $200 \% \mathrm{NPK}+\mathrm{Fe}$. Stage of crop growth had profound influence on the available nitrogen. Higher values of available nitrogen were observed at crown root initiation stage $\left(219.47 \mathrm{~kg} \mathrm{ha}^{-1}\right)$ followed by anthesis $\left(202.64 \mathrm{~kg} \mathrm{ha}^{-1}\right)$ and maturity $\left(182.76 \mathrm{~kg} \mathrm{ha}^{-1}\right)$ over both the period of cropping cycle. The fertilisation $\times$ stage interaction was significant at the $5 \%$ level. As presumed, the higher values

\begin{tabular}{|c|c|c|c|c|c|c|c|c|}
\hline \multirow[t]{2}{*}{ Treatment } & \multicolumn{2}{|c|}{ Grain $\mathrm{K}$ content $(\%)$} & \multicolumn{2}{|c|}{ Grain K uptake } & \multicolumn{2}{|c|}{ Straw K content $(\%)$} & \multicolumn{2}{|c|}{ Straw K uptake } \\
\hline & $2010-2011$ & $2011-2012$ & $2010-2011$ & 2011-2012 & 2010-2011 & 2011-2012 & $2010-2011$ & 2011-2012 \\
\hline $100 \%$ NPK & 0.44 & 0.43 & 20.50 & 21.16 & 1.70 & 1.71 & 128.41 & 132.63 \\
\hline $125 \%$ NPK & 0.46 & 0.46 & 22.59 & 22.76 & 1.71 & 1.72 & 134.41 & 134.33 \\
\hline $150 \%$ NPK & 0.48 & 0.48 & 23.72 & 23.99 & 1.76 & 1.75 & 138.51 & 139.65 \\
\hline $175 \%$ NPK & 0.54 & 0.53 & 26.73 & 26.93 & 1.84 & 1.84 & 145.49 & 149.10 \\
\hline $200 \%$ NPK & 0.60 & 0.59 & 29.79 & 30.54 & 2.05 & 2.03 & 163.80 & 164.39 \\
\hline $100 \% \mathrm{NPK}+\mathrm{Fe}$ & 0.44 & 0.44 & 20.99 & 21.62 & 1.71 & 1.70 & 127.96 & 130.73 \\
\hline $125 \% \mathrm{NPK}+\mathrm{Fe}$ & 0.47 & 0.46 & 22.98 & 22.72 & 1.72 & 1.76 & 133.99 & 138.22 \\
\hline $150 \% \mathrm{NPK}+\mathrm{Fe}$ & 0.49 & 0.48 & 24.21 & 24.54 & 1.76 & 1.78 & 137.46 & 141.98 \\
\hline $175 \% \mathrm{NPK}+\mathrm{Fe}$ & 0.54 & 0.53 & 26.99 & 27.40 & 1.83 & 1.87 & 145.67 & 149.92 \\
\hline $200 \% \mathrm{NPK}+\mathrm{Fe}$ & 0.59 & 0.61 & 29.71 & 31.81 & 2.05 & 2.01 & 164.21 & 161.96 \\
\hline \multirow[t]{3}{*}{$\operatorname{LSD}(p=0.05)$} & \multicolumn{2}{|c|}{ T- 0.03} & \multicolumn{2}{|c|}{ T- 2.01} & \multicolumn{2}{|c|}{ T- 0.05} & \multicolumn{2}{|c|}{ T- 9.65} \\
\hline & \multicolumn{2}{|c|}{ Y- NS } & \multicolumn{2}{|c|}{ Y- NS } & \multicolumn{2}{|c|}{ Y-NS } & \multicolumn{2}{|c|}{ Y-NS } \\
\hline & \multicolumn{2}{|c|}{$\mathrm{T} \times \mathrm{Y}-\mathrm{NS}$} & \multicolumn{2}{|c|}{$\mathrm{T} \times \mathrm{Y}-\mathrm{NS}$} & \multicolumn{2}{|c|}{$\mathrm{T} \times \mathrm{Y}-\mathrm{NS}$} & \multicolumn{2}{|c|}{$\mathrm{T} \times \mathrm{Y}-\mathrm{NS}$} \\
\hline
\end{tabular}


were associated with $200 \% \mathrm{NPK}$ or $200 \% \mathrm{NPK}+\mathrm{Fe}$ at CRI stage and it declines as the plants approached towards maturity, because CRI is the most important transitional stage when the wheat crop breaks dormancy and begins active growth. So, there is lowest nutrient requirement, hence higher values of available nutrients.

Available phosphorus was significantly increased by fertilizer addition. Available phosphorus ranged from 13.76-30.79 kg $\mathrm{ha}^{-1}$ and 11.21-29.13 $\mathrm{kg} \mathrm{ha}^{-1}$ for the cropping year 2010-2011 and 2011-2012 respectively (Table 8). Considering the mean values over the two cropping season, the $200 \%$ NPK and $200 \% \mathrm{NPK}+\mathrm{Fe}$ showed higher values of available phosphorus $\left(28.95 \mathrm{~kg} \mathrm{ha}^{-1}\right.$ and $\left.29.96 \mathrm{~kg} \mathrm{ha}^{-1}\right)$. Crop growth stages also found to be significantly affecting the available phosphorus.
The higher values were observed at CRI stage $\left(25.30 \mathrm{~kg} \mathrm{ha}^{-1}\right)$ followed by anthesis $\left(22.47 \mathrm{~kg} \mathrm{ha}^{-1}\right)$ and maturity $(18.21 \mathrm{~kg}$ $\mathrm{ha}^{-1}$ ). Considering the year of study, the pattern of variation of available phosphorus in the soil during the two years of study was similar; however, available phosphorus was higher in the first year $\left(23.14 \mathrm{~kg} \mathrm{ha}^{-1}\right)$ in comparison to the data (20.84 $\left.\mathrm{kg} \mathrm{ha}^{-1}\right)$ received at the second cropping season. There were significant interaction effects of treatments and stages of wheat growth on available phosphorus content of soil. Available phosphorus at CRI stage was found to be higher for treatments receiving high phosphorus; Data showed higher values of available phosphorus at $200 \%$ NPK $\left(33.13 \mathrm{~kg} \mathrm{ha}^{-1}\right)$ or $200 \%$ $\mathrm{NPK}+\mathrm{Fe}\left(32.51 \mathrm{~kg} \mathrm{ha}^{-1}\right)$ (representing 200\% NPK) treatment at CRI stage over the two cropping cycle.

\begin{tabular}{|c|c|c|c|c|c|c|c|c|c|}
\hline \multirow[t]{2}{*}{ Treatments } & \multicolumn{3}{|c|}{$2010-2011$} & \multirow[t]{2}{*}{ Mean } & \multicolumn{3}{|c|}{ 2011-2012 } & \multirow[b]{2}{*}{ Mean } & \multirow[b]{2}{*}{ Overall Mear } \\
\hline & CRI & Anthesis & Maturity & & CRI & Anthesis & Maturity & & \\
\hline $100 \%$ NPK & 173.64 & 155.86 & 149.31 & 159.60 & 179.25 & 170.85 & 156.14 & 168.75 & 164.18 \\
\hline $125 \% \mathrm{NPK}$ & 192.59 & 181.32 & 164.93 & 179.62 & 198.92 & 185.71 & 168.43 & 184.35 & 181.98 \\
\hline $150 \%$ NPK & 213.08 & 195.16 & 176.71 & 194.98 & 220.43 & 202.61 & 180.73 & 201.25 & 198.12 \\
\hline $175 \% \mathrm{NPK}$ & 223.33 & 212.06 & 197.72 & 211.03 & 228.62 & 214.39 & 189.44 & 210.82 & 210.93 \\
\hline $200 \%$ NPK & 269.42 & 253.55 & 228.45 & 250.47 & 281.89 & 269.71 & 229.39 & 260.33 & 255.40 \\
\hline $100 \% \mathrm{NPK}+\mathrm{Fe}$ & 167.44 & 153.43 & 144.22 & 155.03 & 182.01 & 174.44 & 156.14 & 170.86 & 162.95 \\
\hline $125 \% \mathrm{NPK}+\mathrm{Fe}$ & 195.97 & 185.42 & 165.96 & 182.45 & 201.58 & 187.88 & 175.24 & 188.23 & 185.34 \\
\hline $150 \% \mathrm{NPK}+\mathrm{Fe}$ & 216.16 & 197.71 & 176.20 & 196.69 & 220.25 & 200.21 & 178.17 & 199.54 & 198.12 \\
\hline $175 \% \mathrm{NPK}+\mathrm{Fe}$ & 245.33 & 215.45 & 191.06 & 217.28 & 226.06 & 208.24 & 183.80 & 206.04 & 211.66 \\
\hline $200 \% \mathrm{NPK}+\mathrm{Fe}$ & 277.62 & 239.45 & 213.65 & 243.57 & 275.75 & 249.25 & 229.39 & 251.46 & 247.52 \\
\hline Mean & 217.46 & 198.94 & 180.82 & & 221.48 & 206.33 & 184.69 & & \\
\hline \multirow[t]{2}{*}{$\operatorname{LSD}(p=0.05)$} & & $\mathrm{T}$ & S & $\mathrm{Y}$ & $\mathrm{T} \times \mathrm{S}$ & $\mathrm{T} \times \mathrm{Y}$ & $\mathrm{S} \times \mathrm{Y}$ & $\mathrm{T} \times \mathrm{S} \times \mathrm{Y}$ & \\
\hline & & 11.58 & 9.77 & NS & 12.88 & NS & NS & NS & \\
\hline
\end{tabular}

Table 8: Available phosphorus $\left(\mathrm{kg} \mathrm{ha}^{-1}\right)$ as influenced by various treatments at CRI, anthesis and maturity stages of wheat crop

\begin{tabular}{|c|c|c|c|c|c|c|c|c|c|}
\hline \multirow[t]{2}{*}{ Treatments } & \multicolumn{3}{|c|}{ 2010-2011 } & \multirow[t]{2}{*}{ Mean } & \multicolumn{3}{|c|}{ 2011-2012 } & \multirow[t]{2}{*}{ Mean } & \multirow{2}{*}{$\begin{array}{l}\text { Overal } \\
\text { Mean }\end{array}$} \\
\hline & CRI & Anthesis & Maturity & & CRI & Anthesis & Maturity & & \\
\hline $100 \% \mathrm{NPK}$ & 17.29 & 14.57 & 11.23 & 14.37 & 14.77 & 12.79 & 9.25 & 12.27 & 13.32 \\
\hline $125 \% \mathrm{NPK}$ & 23.08 & 20.58 & 17.46 & 20.37 & 19.59 & 16.62 & 13.55 & 16.59 & 18.48 \\
\hline $150 \% \mathrm{NPK}$ & 27.73 & 24.67 & 19.22 & 23.87 & 25.21 & 21.21 & 17.29 & 21.24 & 22.56 \\
\hline $175 \%$ NPK & 30.33 & 26.88 & 23.36 & 26.86 & 28.66 & 26.68 & 20.47 & 25.27 & 26.06 \\
\hline $200 \%$ NPK & 34.64 & 29.85 & 25.46 & 29.99 & 31.61 & 29.63 & 22.52 & 27.92 & 28.95 \\
\hline $100 \% \mathrm{NPK}+\mathrm{Fe}$ & 16.44 & 14.63 & 10.22 & 13.76 & 13.47 & 11.49 & 8.68 & 11.21 & 12.49 \\
\hline $125 \% \mathrm{NPK}+\mathrm{Fe}$ & 22.96 & 19.84 & 15.98 & 19.60 & 19.59 & 17.61 & 15.99 & 17.73 & 18.66 \\
\hline $150 \% \mathrm{NPK}+\mathrm{Fe}$ & 28.13 & 24.44 & 19.77 & 24.11 & 25.55 & 22.55 & 18.14 & 22.08 & 23.10 \\
\hline $175 \% \mathrm{NPK}+\mathrm{Fe}$ & 31.55 & 27.39 & 24.17 & 27.70 & 28.44 & 26.46 & 20.01 & 24.97 & 26.34 \\
\hline $200 \% \mathrm{NPK}+\mathrm{Fe}$ & 34.87 & 31.24 & 26.26 & 30.79 & 32.12 & 30.14 & 25.14 & 29.13 & 29.96 \\
\hline Mean & 26.70 & 23.41 & 19.31 & & 23.90 & 21.52 & 17.10 & & \\
\hline \multirow[t]{2}{*}{$\operatorname{LSD}(p=0.05)$} & & $\mathrm{T}$ & S & $\mathrm{Y}$ & $\mathrm{T} \times \mathrm{S}$ & $\mathrm{T} \times \mathrm{Y}$ & $\mathrm{S} \times \mathrm{Y}$ & $\mathrm{T} \times \mathrm{S} \times \mathrm{Y}$ & \\
\hline & & 2.88 & 2.04 & NS & 3.01 & NS & NS & NS & \\
\hline
\end{tabular}


Fertilization significantly affects the available potassium content in soils; available potassium varies from 187.04-260.37 $\mathrm{kg} \mathrm{ha}^{-1}$ in the cropping year 2010-2011 and $185.87-257.18 \mathrm{~kg}$ $\mathrm{ha}^{-1}$ in the subsequent season (2011-2012); whereas the pooled mean ranges from $186.46-257.67 \mathrm{~kg} \mathrm{ha}^{-1}$. As expected, $200 \%$ NPK or $200 \% \mathrm{NPK}+\mathrm{Fe}$ (treatments those received higher amount of MoP as a source of potassium fertilizer) were found to have higher available potassium. Moreover, available potassium was significantly affected by the growing stages of wheat crop. In the first cropping season, CRI stage showed $232.24 \mathrm{~kg} \mathrm{ha}^{-1}$, anthesis- $224.30 \mathrm{~kg} \mathrm{ha}^{-1}$ and maturity- 202.51 $\mathrm{kg} \mathrm{ha}^{-1}$; whereas in 2011-2012, the values were CRI-235.56 $\mathrm{kg} \mathrm{ha}^{-1}$, anthesis- $220.19 \mathrm{~kg} \mathrm{ha}^{-1}$ and maturity-204.18 $\mathrm{kg} \mathrm{ha}^{-1}$ (Table 9). The interaction effects of treatments and stages of growth on available potassium content in soil reveal that available potassium at CRI stage was found to be higher for treatments receiving high potassium; Data showed higher values of available potassium at $200 \%$ NPK $\left(280.53 \mathrm{~kg} \mathrm{ha}^{-1}\right)$ or $200 \% \mathrm{NPK}+\mathrm{Fe}\left(266.41 \mathrm{~kg} \mathrm{ha}^{-1}\right)$ (representing $200 \% \mathrm{NPK}$ ) treatment at CRI stage over the two cropping cycle. Results from Barthwal et al., 2013 revealed that the available nitrogen, phosphorus and potassium content increased in soil under wheat with increasing application of nutrients (NPK) through inorganic fertilizers.

\subsection{Nutrient harvest indices}

Results from nitrogen, phosphorus and potassium harvest indices were not found to be significantly affected by any of the treatments (Table 10). This is due to proportionate uptake of these nutrients by the grain and straw with increasing doses

\begin{tabular}{|c|c|c|c|c|c|c|c|c|c|}
\hline \multirow[t]{2}{*}{ Treatments } & \multicolumn{3}{|c|}{$2010-2011$} & \multirow[t]{2}{*}{ Mean } & \multicolumn{3}{|c|}{ 2011-2012 } & \multirow[t]{2}{*}{ Mean } & \multirow[t]{2}{*}{ Overall Mean } \\
\hline & CRI & Anthesis & Maturity & & CRI & Anthesis & Maturity & & \\
\hline $100 \%$ NPK & 199.73 & 191.15 & 170.24 & 187.04 & 200.14 & 187.11 & 170.36 & 185.87 & 186.46 \\
\hline $125 \%$ NPK & 209.44 & 202.35 & 178.83 & 196.87 & 215.68 & 199.06 & 181.56 & 198.77 & 197.82 \\
\hline $150 \%$ NPK & 224.00 & 218.77 & 200.85 & 214.54 & 228.75 & 218.84 & 202.47 & 216.69 & 215.61 \\
\hline $175 \%$ NPK & 259.47 & 255.73 & 222.51 & 245.90 & 260.11 & 248.71 & 225.61 & 244.81 & 245.36 \\
\hline $200 \%$ NPK & 282.61 & 267.31 & 231.19 & 260.37 & 278.45 & 251.33 & 235.14 & 254.97 & 257.67 \\
\hline $100 \% \mathrm{NPK}+\mathrm{Fe}$ & 205.94 & 193.01 & 171.73 & 190.23 & 204.11 & 191.22 & 173.35 & 189.56 & 189.89 \\
\hline $125 \% \mathrm{NPK}+\mathrm{Fe}$ & 209.07 & 201.60 & 190.77 & 200.48 & 213.44 & 200.55 & 194.25 & 202.75 & 201.61 \\
\hline $150 \% \mathrm{NPK}+\mathrm{Fe}$ & 216.53 & 211.68 & 198.61 & 208.94 & 220.16 & 209.14 & 200.97 & 210.09 & 209.52 \\
\hline $175 \% \mathrm{NPK}+\mathrm{Fe}$ & 240.43 & 243.41 & 225.49 & 236.44 & 253.01 & 238.26 & 225.99 & 239.09 & 237.77 \\
\hline $200 \% \mathrm{NPK}+\mathrm{Fe}$ & 275.15 & 257.97 & 234.87 & 256.00 & 281.76 & 257.67 & 232.11 & 257.18 & 256.59 \\
\hline Mean & 232.24 & 224.30 & 202.51 & & 235.56 & 220.19 & 204.18 & & \\
\hline \multirow[t]{2}{*}{$\operatorname{LSD}(p=0.05)$} & & $\mathrm{T}$ & S & Y & $\mathrm{T} \times \mathrm{S}$ & $\mathrm{T} \times \mathrm{Y}$ & $\mathrm{S} \times \mathrm{Y}$ & $\mathrm{T} \times \mathrm{S} \times \mathrm{Y}$ & \\
\hline & & 8.55 & 11.22 & NS & 12.05 & NS & NS & NS & \\
\hline
\end{tabular}

Table 10: Nutrient harvest indices as influenced by various treatments in wheat crop

\begin{tabular}{|c|c|c|c|c|c|c|c|c|c|c|c|c|}
\hline \multirow[t]{2}{*}{ Treatments } & \multicolumn{3}{|c|}{ NHI (\%) } & \multicolumn{3}{|c|}{ PHI (\%) } & \multicolumn{3}{|c|}{ KHI (\%) } & \multicolumn{3}{|c|}{ FeHI (\%) } \\
\hline & $2010-11$ & $2011-12$ & Mean & $2010-11$ & 2011-12 & Mean & $2010-11$ & $2011-12$ & Mean & $2010-11$ & $2011-12$ & Mean \\
\hline $100 \%$ NPK & 72.08 & 72.45 & 72.27 & 85.48 & 85.19 & 85.34 & 11.94 & 12.19 & 12.07 & 7.85 & 7.02 & 7.44 \\
\hline $125 \%$ NPK & 71.28 & 71.94 & 71.61 & 85.27 & 85.52 & 85.40 & 11.87 & 12.33 & 12.10 & 8.14 & 8.03 & 8.09 \\
\hline $150 \%$ NPK & 71.33 & 71.06 & 71.20 & 84.07 & 84.02 & 84.05 & 11.77 & 12.05 & 11.91 & 8.58 & 8.68 & 8.63 \\
\hline $175 \%$ NPK & 70.82 & 70.98 & 70.90 & 83.02 & 83.16 & 83.09 & 11.47 & 11.58 & 11.53 & 8.60 & 8.33 & 8.47 \\
\hline $200 \%$ NPK & 70.81 & 71.18 & 71.00 & 82.09 & 82.08 & 82.09 & 10.78 & 11.04 & 10.91 & 8.65 & 9.12 & 8.89 \\
\hline $100 \% \mathrm{NPK}+\mathrm{Fe}$ & 73.46 & 72.24 & 72.85 & 86.23 & 84.72 & 85.48 & 12.23 & 12.30 & 12.27 & 8.63 & 7.63 & 8.13 \\
\hline $125 \% \mathrm{NPK}+\mathrm{Fe}$ & 72.74 & 71.15 & 71.95 & 85.62 & 84.42 & 85.02 & 12.10 & 11.88 & 11.99 & 8.55 & 8.42 & 8.49 \\
\hline $150 \% \mathrm{NPK}+\mathrm{Fe}$ & 71.91 & 71.29 & 71.60 & 84.23 & 84.15 & 84.19 & 11.86 & 11.99 & 11.93 & 8.73 & 8.80 & 8.77 \\
\hline $175 \% \mathrm{NPK}+\mathrm{Fe}$ & 70.97 & 70.67 & 70.82 & 83.57 & 83.49 & 83.53 & 11.48 & 11.69 & 11.59 & 8.65 & 8.84 & 8.75 \\
\hline $200 \% \mathrm{NPK}+\mathrm{Fe}$ & 70.51 & 71.61 & 71.06 & 83.33 & 82.61 & 82.97 & 10.75 & 11.28 & 11.02 & 8.67 & 8.97 & 8.82 \\
\hline Mean & 71.59 & 71.46 & & 84.29 & 83.94 & & 11.63 & 11.83 & & 8.51 & 8.38 & \\
\hline $\mathrm{CD}(p=0.05)$ & NS & NS & & NS & NS & & NS & NS & & 0.62 & 0.73 & \\
\hline
\end{tabular}


of fertilization. Moreover, Fe harvest index was found to be affected by the fertilizer doses. Fe harvest index was found to be increased in treatments receiving high fertilizer doses and this may be due to two reasons; in wheat, foliar spray increases grain $\mathrm{Fe}$ concentration by $10 \%$ (Aciksoz et al., 2011) and secondly, high nitrogen nutrition of wheat plants may lead to increase in grain $\mathrm{Fe}$ as reported by Kutman and co-workers in 2010.

\section{Conclusion}

Super-optimal doses of fertilizers (200\% NPK) had positive effect on yield and yield components; but the rate of increase diminishes with additional fertilizers applied over the recommended dose $(100 \%$ NPK) for wheat. The yield increase under high fertilization may be attributed to increased number of spikes $\mathrm{m}^{-2}$ and grain weight spikes ${ }^{-1}$. Soil fertility levels was found to be improved under the plots receiving excess fertilizers, keeping a possibility of aggravating the nutrient losses in various forms; available nutrients (NPK) under the various phenological stages of wheat crop followed the pattern: CRI $>$ Anthesis $>$ Maturity. Foliar iron application increased the iron harvest index, which can be considered as a remedy to tackle the problem of malnutrition of iron in India.

\section{References}

Aciksoz, S.B., Yazici, A., Ozturk, L., Cakmak, I., 2011. Biofortification of wheat with iron through soil and foliar application of nitrogen and iron fertilizers. Plant and Soil 349, 215-225.

Arif, M., Chohan, M.A., Ali, S., Gul, R., Khan, S., 2006. Response of wheat to foliar application of nutrients. Journal of Agricultural and Biological Science 1, 30-34.

Babaeian, M., Tavassoli, A., Ghanbari, A., Esmaeilian, Y., Fahimifard, M., 2011. Effects of foliar micronutrient application on osmotic adjustments, grain yield and yield components in sunflower (Alstar cultivar) under water stress at three stages. African Journal of Agricultural Research 6, 1204-1208.

Bameri, M., Abdolshahi, R., Mohammadi-Nejad, G., Yousefi, K., Tabatabaie, S.M., 2012. Effect of different microelement treatment on wheat (Triticum aestivum) growth and yield. International Research Journal of Applied and Basic Sciences 3, 219-223.

Barthwal, A., Bharadwaj, A.K., Chaturvedi, S., Pandiaraj, T., 2013. Site specific NPK recommendation in wheat (Triticum aestivum) for sustained crop and soil productivity in mollisols of Tarai region. Indian Journal of Agronomy 58, 208-214.

Chesti, M.H., Kohli, A., Sharma, A.K. 2013. Effect of INM on yield of and nutrient uptake by wheat (Triticum aestivum) and soil properties under intermediate zone of Jammu and Kashmir. Journal of the Indian Society of Soil Science 61, 1-6.

Chuan, L., He, P., Jin, J., Li, S., Grant, C., Xu, X., Qiu, S., Zhao, S., Zhou, W., 2013. Estimating nutrient uptake requirements for wheat in China. Field Crop Research 146, 96-104.

Costa, S.E.V.G.A., Souza, E.D., Anghinoni, I., Flores, J.P.C., Vieira, F.C.B., Martins, A.P., Ferreira, E.V.O., 2010. Patterns in phosphorus and corn root distribution and yield in long-term tillage systems with fertilizer application. Soil and Tillage Research 109, 41-49.

Gomez, K.A., Gomez, A.A., 1984. Statistical Procedures for Agricultural Research. John Wiley and Sons, New York.

Hanway, J.J., Heidel, H., 1952. Soil analysis method as used in Iowa State College soil testing laboratory. Iowa Agriculture 57, 1-31.

Hui-Min, Z., Xue-Yun, Y., Xin-Hua, H., Ming-Gang, X., ShaoMin, H., Hua, L., Bo-Ren, W., 2011. Effect of long-term potassium fertilization on crop yield and potassium effciency and balance under wheat-maize rotation in China. Pedosphere 21, 154-163.

Jackson, M.L., (1973). Soil chemical analysis. New Delhi. Prentice hall of India Pvt. Ltd.

Kutman, U.B., Yildiz, B., Ozturk, L., Cakmak, I., 2010. Biofortification of durum wheat with zinc through and soil and foliar application of nitrogen. Cereal Chemistry $87,1-9$.

Liu, X., Ju, X., Zhang, F., Pan, J., Christie, P., 2003. Nitrogen dynamics and budgets in a winter wheat-maize cropping system in the North China Plain. Field Crops Research 83, 111-124

Lopez-Bellido, R.J., Lopez-Bellido, L., 2001. Efficiency of nitrogen in wheat under Mediterranean conditions: effect of tillage, crop rotation and $\mathrm{N}$ fertilisation. Field Crop Research 71, 31-46

Pathak, H., Singh, Y., Bijay-Singh., 2003. Site-specific nutrient management for improving the productivity of rice-wheat cropping system. In: Yadvinder-Singh et al. (eds) Nutrient management for sustainable rice-wheat cropping system. Natl Agric Tech Project, Indian Counc Agric Res, New Delhi, India, and Punjab Agric Univ, Ludhiana, Punjab, India, pp 79-98.

Piper, C.S., 1967. Soil and Plant analysis. Asia Publishing House. Bombay, India.

SeifiNadergholi, M., Yarnia, M., Rahimzade Khoei, F., 2011. Effect of zinc and manganese and their application method on yield and yield components of common bean 
(Phaseolus vulgaris). Middle-East Journal of Scientific Research 8, 859-865.

Singh, M., Singh, V.P., Reddy, K.S., 2001. Effect of integrated use of fertilizer nitrogen and farmyard manure or green manure on transformation of $\mathrm{N}, \mathrm{K}$ and $\mathrm{S}$ and productivity of rice-wheat system on a Vertisol. Journal of the Indian Society of Soil Science 49, 430-435.

Subbiah, B.V., Asija, G.L., 1956. A rapid procedure for the determination of available nitrogen in soils. Current Science 25, 259-260.

Tang, X., Li, J., Ma, Y., Hao, X., Li, X., 2008. Phosphorus efficiency in long-term ( 15 years) wheat-maize cropping systems with various soil and climate conditions. Field Crops Research 108, 231-237.

Tripathi, S.C., Chander, S., Meena, R.P., 2013. Effect of early sowing, $\mathrm{N}$ levels and seed rates on yield and yield attributes of different wheat (Triticum aestivum) varieties. Indian Journal of Agronomy 58, 63-66.

Vig, A.C., Singh, N.T., 1983. Yield and P uptake by wheat as affected by $\mathrm{P}$ fertilization and soil moisture regime. Fertilizer Research 4, 21-29.

Watanabe, F.S., Olsen, S.R., 1965. Test of ascorbic acid method for determining phosphorus in water and sodium bicarbonate extract of soil. Soil Science Society of America Proceedings 29, 677-678.

Zhao, H.B., Lin, Q., Liu, Y.G., Jiang, W., Liu, J.J., Zhai, Y.J., 2010. Effects of combined application of nitrogen and phosphorus on diurnal variation of photosynthesis at grain-filling stage and grain yield of super high-yielding wheat. Ying Yong Sheng Tai Xue Bao 21, 2545-2550. [Article in Chinese]. 